\title{
Distribution of benthic foraminiferal assemblages in the transitional environment of the Djerba lagoon (Tunisia)
}

\author{
Akram El Kateb ${ }^{1} \cdot$ Claudio Stalder $^{2} \cdot$ Christoph Neururer $^{1} \cdot$ Robin Fentimen $^{1} \cdot$ Jorge E. Spangenberg $^{3} \cdot$ \\ Silvia Spezzaferri ${ }^{1}$
}

\begin{abstract}
The eastern edge of the Djerba Island represents an important tourist pole. However, studies describing the environmental processes affecting this Island are scarce. Although never studied before, the peculiar Djerba lagoon is well known by the local population and by tourists. In July 2014, surface sediment and seawater samples were collected in this lagoon to measure grain size, organic matter content and living foraminiferal assemblages to describe environmental conditions. Seawater samples were also collected and the concentration of 17 chemical elements were measured by ICP-OES. The results show that a salinity gradient along the studied transect clearly impacts seagrass distribution, creating different environmental conditions inside the Djerba lagoon. Biotic and abiotic parameters reflect a transitional environment from hypersaline to normal marine conditions. Living benthic foraminifera show an adaptation to changing conditions within the different parts of the lagoon. In particular, the presence of Ammonia spp. and Haynesina depressula correlates with hypersaline waters, whilst Brizalina striatula characterizes the parts of the lagoon colonized by seagrass. Epifaunal species, such as Rosalina vilardeboana and Amphistegina spp. colonize hard substrata present at the transition between the lagoon and the open sea.
\end{abstract}

Keywords Lagoon · Djerba Island · Foraminifera · Transitional environment

\section{Introduction}

Coastal lagoons are present in all continents and are water bodies, generally parallel to the coast line, and separated from the ocean by barriers and by one to more inlets. Water salinity can vary from very low (fresh water) to high

Editorial handling: W. Winkler.

Electronic supplementary material

Akram El Kateb

akram.elkateb@unifr.ch

1 Department of Geosciences, University of Fribourg, Chemin du Musée 6, 1700 Fribourg, Switzerland

2 Federal Office of Public Health FOPH, Schwarzenburgstrasse 157, 3003 Bern, Switzerland

3 Institut of Earth Surface Dynamics (IDYST), University of Lausanne, Building Géopolis, 1015 Lausanne, Switzerland (hypersaline conditions), depending on the hydrological balance (Kjerfve 1994).

A large number of lagoons are present in the Mediterranean Sea. One of the largest and thoroughly studied mainly because of the intense anthropogenic impacts (e.g., tourism) is the Venice lagoon in Italy (e.g. Sfriso et al. 1987, 1992; Livingstone et al. 1995; Bellucci et al. 2002). Additional lagoons along the Italian coast have also been investigated (Bouchet et al. 2018). Other lagoons like Berre and Thau (France) (e.g. Arfi 1989; Point et al. 2007; Chambouvet et al. 2011; Delpy et al. 2012); Mar Menor (Spain) (e.g. García-Pintado et al. 2007); Paradeniz (Turkey) (e.g. Türkmen et al. 2011); and Marina (Egypt) (e.g. El-Gamal et al. 2012) have been studied as a consequence of anthropogenic practices (e.g., tourism, agriculture, sewage) leading to pollution concerns. Along the Tunisian coast, the Bizerte, Ghar El Melh (e.g. Chouba et al. 2007) and El Bibane lagoons (Vela et al. 2008) are known to be impacted by heavy metals, organic pollutants. The most studied is the Bizerte lagoon, located in the northern part of Tunisia (e.g. Mzoughi et al. 2005; Dridi et al. 2007; Louiz 
et al. 2008; Ben-Ameur et al. 2012; Martin et al. 2015, 2016). The high population density and the industrial activities around this large (over $150 \mathrm{~km}^{2}$ ) lagoon represent an environmental threat. The lagoon of Bizerte is therefore of major interest to assess its environmental quality (Martins et al. 2015 and references therein). Although a large part of the Tunisian costal environments have been studied, some important areas were neglected or poorly investigated. For example, the Eastern edge of the Djerba Island is one of the least explored regions in Tunisia, where only grain size distribution related to the dynamic of coastal currents has been studied (Brahim et al. 2014).

Located in front of the south-eastern coast of Tunisia, the Djerba Island is the largest island (Fig. 1) and is surrounded by the Gulf of Gabes to the North and by the Boughrara lagoon to the South-east. Approximatively $2 \mathrm{~km}$ long and $200 \mathrm{~m}$ wide, the Djerba lagoon can be considered as small in comparison to the other Tunisian lagoons. Its northern and western parts are the shallowest whereas the southern part is the deepest. A natural channel connects the lagoon to the sea. Based on the classification of Kjerfve (1986), the Djerba lagoon is a choked lagoon as it connects to the Sea by a single channel. Tidal currents acting along the eastern coast of Djerba modulate the hydrology of the lagoon (Brahim et al. 2014) because tides in this region are some of the highest in the Mediterranean Sea (Sammari et al. 2006). The water depth inside the lagoon varies depending on the tide amplitude although it never exceeds $2 \mathrm{~m}$, following the semidiurnal tide, and the water flows out of the lagoon twice a day.

Most coastal areas in the world are impacted by some level of pollution (Shahidul and Tanaka, 2004) and coastal lagoons are especially vulnerable to anthropogenic

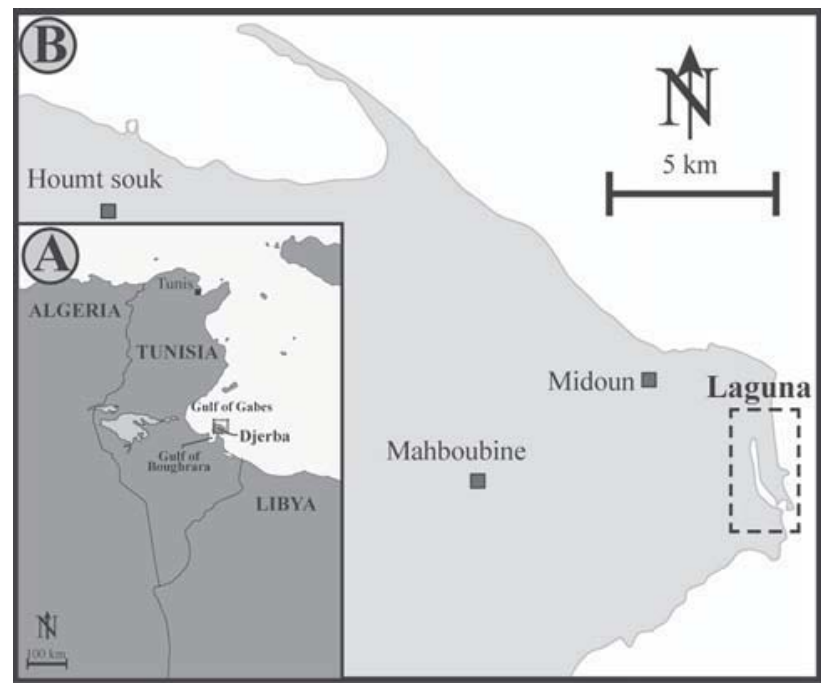

Fig. 1 Location maps of Tunisia and Djerba Island. a Map of Tunisia with location of Djerba Island. b Map of the eastern part of Djerba Island with location of the lagoon activities because they represent ideal environments for different economical activities such as fishing, aquaculture, tourism and agriculture which affect their ecology (Gamito 2008 and references therein). The geographical position of the Djerba lagoon makes it particularly exposed to anthropogenic-related pollution since tourism is very intense especially during summer.

The arid climate in southern Tunisia, has also a strong impact on the environmental setting of the Djerba lagoon. High temperature, low precipitation, changing circulation patterns and the heterogeneity of the sediments in the lagoon may impact and influence environmental conditions of the ecosystems within a few meters.

Benthic foraminifera have been used since the 1960s to describe marine environments (e.g., Schönfeld et al. 2012). Their high density in marine sediments, high species variability, short life cycle and the good preservation of tests in marine sediments make these organisms an ideal tool to describe and monitor marine environments (Gooday 2003; Jorissen et al. 2007; Schönfeld et al. 2012). Coupling investigations on living benthic foraminiferal assemblages with environmental parameters (e.g., physiochemical parameters, grain size, and sedimentary facies) may allow to better understand the environmental and ecological conditions in the Djerba lagoon. Availability of organic matter (OM) in sediments, representing as a food source, can influence the benthic species distribution, including foraminifera (e.g., Martins et al. 2015).

Eutrophication of marine environments can be the result of anthropogenic activity, which is induced by an increasing supply of OM into the ecosystems (Nixon 1995). The eutrophic state of marine environments can be described using OM (and its compounds) as a proxy because it reflects a higher primary productivity due to the increase of nutrient input (Dell'Anno et al. 2002, Martin et al. 2015, 2016).

Heavy metals, although minor elements in seawater, are also good pollution and/or anthropogenic indicators (Callender 2003).

The aim of this study is to describe for the first time the Djerba lagoon by investigating hydrodynamic patterns, seagrass meadow distribution and water physiochemical parameters. This approach will allow to describe the environmental conditions that characterize the different parts of the lagoon and to correlate them with living benthic foraminiferal distributions. This study also provides a preliminary assessment of the anthropogenic impact on this lagoon. 


\section{Material and methods}

\subsection{Sampling and station description}

Ten stations have been sampled (LA-01 to LA-10) in the Djerba lagoon on July 2014. Stations are located along a transect from the internal to the external part of the lagoon (Table 1 and Fig. 2). Most of the stations are located inside the lagoon, only station LA-10 is located outside the lagoon on the rocky substrate on the eastern side of the lagoon.

For each station, surface grab sediment (the first centimeter) and seawater samples were collected. Two subsamples were collected: (1) approximatively $15 \mathrm{~cm}^{3}$ of sediment per station were collected in falcon tubes for geochemical analyses (Rock-Eval, stable carbon isotope ratio of $\mathrm{OM}, \mathrm{C}, \mathrm{H}, \mathrm{N}$ elemental analysis) and were stored at $4{ }^{\circ} \mathrm{C}$; (2) around $50 \mathrm{~cm}^{3}$ of surface sediment samples were collected for living (stained) foraminiferal assemblage analysis following Schönfeld et al. (2012) protocols. Sediments were placed in a rose Bengal solution $(2 \mathrm{~g} / \mathrm{L}$ in alcohol at $90 \%$ ) for at least 14 days to stain living foraminifera. At station LA-10 two different sediment samples were taken: (i) sediment layout on the bottom of cavities (LA-10a) (ii) sediment trapped in the algal carpet (LA-10b). Both samples (LA-10a and LA-10b) were also analyzed for living foraminifera, only the sediment trapped in the algae carpet were used for geochemistry.

At each station, $120 \mathrm{~mL}$ of surface seawater samples were collected in high density polyethylene Nalgene ${ }^{\circledR}$ bottles. Seawater samples were acidified $(\mathrm{pH} 1)$ by adding $5 \mathrm{~mL}$ of concentrated nitric acid to avoid precipitation of coordination complexes and were stored at $4{ }^{\circ} \mathrm{C}$.

\subsection{Sediment and seawater analysis}

Surface sediment samples for geochemical analysis were dried in a ventilated oven at $35^{\circ} \mathrm{C}$ until reaching a constant weight. Rock-Eval analyses were performed on approximatively $100 \mathrm{mg}$ of bulk surface sediment previously crushed in an agate mortar. Rock-Eval analyses were performed following Rock-Eval6 technology to obtain total organic carbon (TOC) content (wt\%), hydrogen index $(\mathrm{HI})$, oxygen index (OI), S1 S2 and S3 peaks, maximal temperature $\left(\mathrm{T}_{\max }\right)$ and mineral carbon $(\mathrm{MINC})$ content on approximately $100 \mathrm{mg}$ bulk sediment. HI correspond to the free hydrocarbons present in the sample (mg HC/g TOC, measured on S1 peak) and OI to the amount of hydrocarbons containing oxygen that are produced during the thermal cracking of kerogen $\left(\mathrm{mg} \mathrm{CO}_{2} / \mathrm{g}\right.$ TOC, measured on $\mathrm{S} 2$ and $\mathrm{S} 3$ peaks). $\mathrm{T}_{\max }$ is measured at the maximum of $\mathrm{S} 2$ peak. High temperatures (up to $850{ }^{\circ} \mathrm{C}$ ) allow MINC determination through mineral carbon oxidation (Espitalié et al. 1985; Lafargue et al. 1998).

Total carbon, hydrogen and nitrogen $(\mathrm{C}, \mathrm{H}, \mathrm{N})$ contents (in $\mathrm{wt} \%$ ) were measured in the surface sediment samples using a Thermo Finnigan Flash EA 1112 gas chromatography analyser. Rock-Eval and $\mathrm{C}, \mathrm{H}, \mathrm{N}$ analyses were performed at the laboratory of Sediment Geochemistry at the University of Lausanne on approximately $100 \mathrm{mg}$ bulk sediment.

Carbonate minerals in surface sediment were dissolved using a $10 \% \mathrm{HCl}$ solution at $50{ }^{\circ} \mathrm{C}$. This process was repeated twice and the sediment was rinsed with milli-Q water. Stable carbon isotope ratio of $\mathrm{OM}\left(\delta^{13} \mathrm{C}_{\mathrm{OM}}\right)$ from surface sediment samples were measured at the Stable Isotopes Laboratory of the University of Lausanne by flash combustion on a Carlo Erba 1108 elemental analyser connected to a Thermo Fisher Scientific Delta V Plus isotope ratio mass spectrometry that was operated in a continuous helium flow mode via a Conflo III split interface.

Major elements ( $\mathrm{Na}, \mathrm{Mg}, \mathrm{S}, \mathrm{K}, \mathrm{Ca}$ and $\mathrm{Sr}$ ) and trace elements ( $\mathrm{Li}, \mathrm{Al}, \mathrm{Si}, \mathrm{P}, \mathrm{Cr}, \mathrm{Mn}, \mathrm{Fe}, \mathrm{Ni}, \mathrm{Cu}, \mathrm{As}$, and $\mathrm{Cd}$ ) were measured in seawater samples by inductively coupled plasma optical emission spectroscopy (ICP-OES) at ATI Aquaristik lab at Hamm in Germany. Measurements were performed with a Spectro Arcos 2 ICP-OES analyser with

Table 1 GPS coordinates of the investigated stations together with their simplified sediment descriptions

\begin{tabular}{lll}
\hline Station & Description & GPS coordinate $(\mathrm{DM})$ \\
\hline LA-01 & Fine sand with abundant black gastropods & $\mathrm{N} 33^{\circ} 48.419^{\prime} / \mathrm{E} 011^{\circ} 02.966^{\prime}$ \\
LA-02 & Fine sand with abundant black gastropods & $\mathrm{N} 33^{\circ} 48.300^{\prime} / \mathrm{E} 011^{\circ} 02.955^{\prime}$ \\
LA-03 & Fine sediment with abundant burrows & $\mathrm{N} 33^{\circ} 47.955^{\prime} / \mathrm{E} 011^{\circ} 02.966^{\prime}$ \\
LA-04 & Fine sediment with abundant burrows & $\mathrm{N} 33^{\circ} 47.757^{\prime} / \mathrm{E} 011^{\circ} 03.011^{\prime}$ \\
LA-05 & Fine sand & $\mathrm{N} 33^{\circ} 47.605^{\prime} / \mathrm{E} 011^{\circ} 03.095^{\prime}$ \\
LA-06 & Quartz sand with Posidonia oceanica meadow & $\mathrm{N} 33^{\circ} 47.466^{\prime} / \mathrm{E} 011^{\circ} 03.207^{\prime}$ \\
LA-07 & Quartz sand with Posidonia oceanica meadow & $\mathrm{N} 33^{\circ} 47.348^{\prime} / \mathrm{E} 011^{\circ} 03.346^{\prime}$ \\
LA-08 & Fine sand & $\mathrm{N} 33^{\circ} 47.370^{\prime} / \mathrm{E} 011^{\circ} 03.384^{\prime}$ \\
LA-09 & Quartz sand with Posidonia oceanica meadow & $\mathrm{N} 33^{\circ} 47.480^{\prime} / \mathrm{E} 011^{\circ} 03.524^{\prime}$ \\
LA-10 & Rocky substrate (beachrock) & $\mathrm{N} 33^{\circ} 47.614^{\prime} / \mathrm{E} 011^{\circ} 03.611^{\prime}$ \\
\hline
\end{tabular}




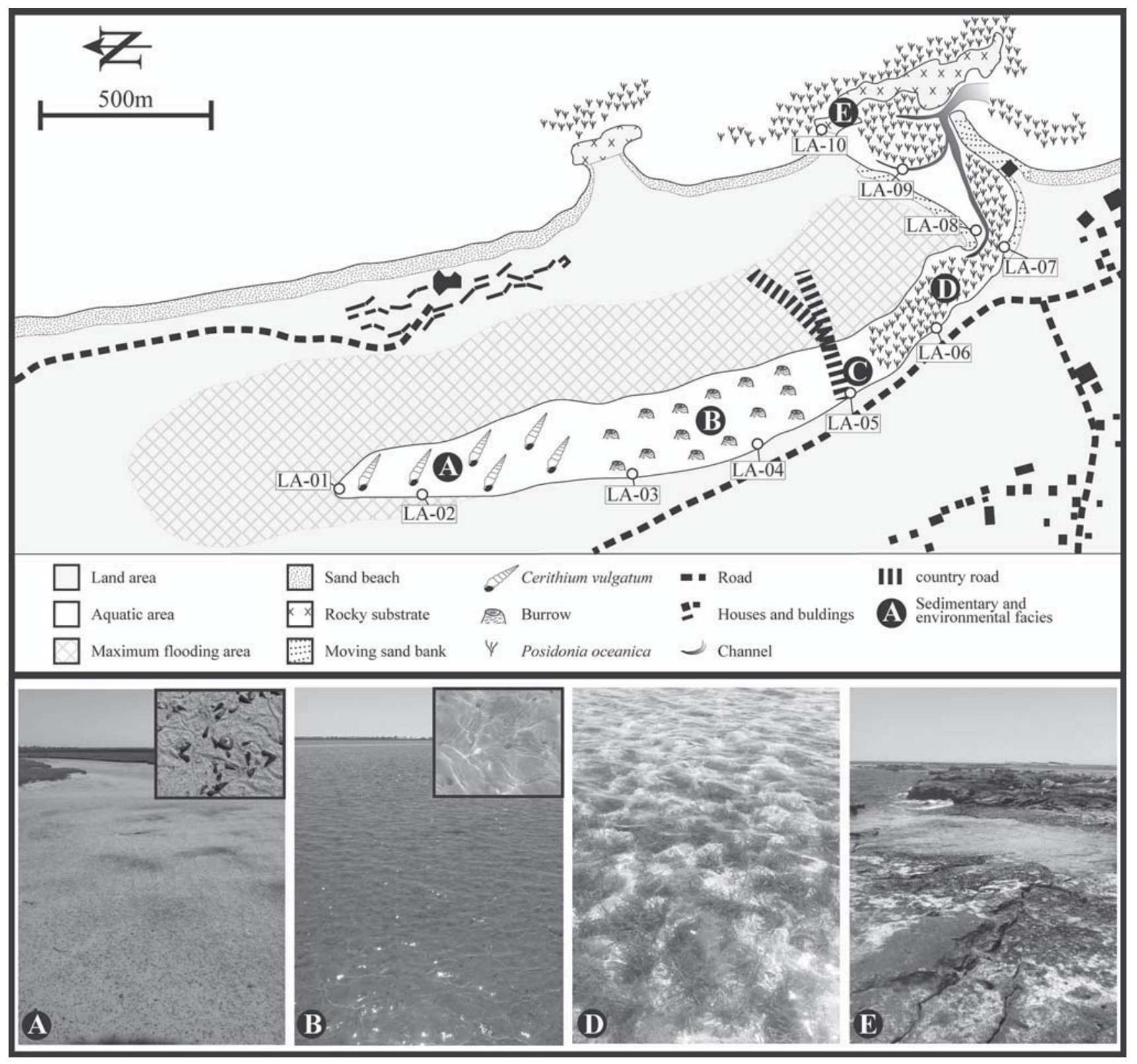

Fig. 2 2D maps of the Djerba lagoon with the distribution of flora, fauna and sediment characteristics and distribution of the different facies

four points of calibration for major elements and eight points of calibration for trace elements. For each sample and each chemical element, four measurements were performed and corresponding average values were calculated. Every five measurements, a control sample was measured to check the stability of the plasma torch and to avoid any shift during the set of measurements.

Concentration factors $(\mathrm{CF})$ were calculated from the ICP-OES data set. The concentration of each element and of each sample was divided by the concentration of a reference seawater sample, considered as representing normal seawater conditions. Station LA-10 was chosen as the reference site to represent values of seawater because it is located outside the lagoon.

Grain size analysis was performed on the stained (rose Bengal) surface sediments. The samples were wet sieved through four mesh sieves: 500, 250, 125 and $63 \mu \mathrm{m}$. Each fraction $(<63,63-125 ; 125-250 ; 250-500$ and $>500 \mu \mathrm{m})$ was dried in a ventilated oven at $35{ }^{\circ} \mathrm{C}$ and weighed to calculate the proportion (wt $\%$ ).

Following the FOBIMO protocols (Schönfeld et al. 2012), stained foraminifera were picked from plummer cells for each size fraction. Taxonomy was done to species level following the work of Cimerman and Langer (1991), Hottinger and Halicz (1993), Loeblich and Tappan (1994), 
Milker and Schmiedl (2012). Quantitative data were treated with the software Primer 6 (Clarke and Gorley 2006). The number of living foraminifera (for each species) per samples was standardize for an equivalent volume of sediment of $100 \mathrm{~cm}^{3}$, then the data set was double square root transformed to limit the contribution of most abundant species (Field et al. 1982). The Bray-Curtis (dis-)similarity was calculated and used to obtain the non-metric MultiDimensional Scaling-nMDS plots. The contribution of each species to the total average similarity and dissimilarity between different groups and within single groups where determined by using the similarity percentage analysis (SIMPER). The density of living foraminifera was calculated for every station by dividing the number of living specimens by the total volume of sediment. To compare the diversity pattern of living (stained) benthic foraminifera, in addition to the number of species per stations, the ShannonIndex $\left(\mathrm{H}^{\prime}\right)$ and Fisher's $\alpha$ Index were calculated with the software Primer 6 (Clarke and Gorley 2006).

\section{Results}

\subsection{Sedimentary and environmental facies}

Based on the visual sample description and in situ observation of the sampling sites, five facies were distinguished (Fig. 2):

- Facies A groups stations LA-01 and LA-02, it correspond to the inner part of the lagoon. The main characteristic of this facies is the abundance of living Cerithium vulgatum (gastropod).The numerous furrows on the sediments' surface confirm this observation. The water depth was very shallow in comparison to the other areas of the lagoon $(<10 \mathrm{~cm})$.

- Facies B groups stations LA-03 and LA-04. This facies is characterized by the presence of numerous burrows. Unfortunately, the organisms responsible for these burrows were not observed and thus, could not be identified.

- Facies C groups station LA-05 and LA-08. This facies does not show any peculiar characteristics, sediments are close to pure sand. However, station LA-05 is located on a country road crossing the lagoon.

- Facies D groups stations LA-06, LA-07 and LA-09. This facies is characterized by the seagrass Posidonia oceanica.

- Facies $\mathrm{E}$ is represented by station LA-10. The bottom is a consolidated sandstone and is probably beachrock. However, numerous cavities present are filled by soft sediments of two types: (i) sediment layout at the bottom of the cavity (i.e. LA-10a). (ii) sediment trapped by a carpet of algae on the wall of these cavities (i.e. LA-10b).

Sediment grain sizes are fairly evenly distributed across all stations. However, sample LA-10a which is relatively coarser (Fig. 3) with the fractions $>500$ and 250-500 $\mu \mathrm{m}$ reaching 71 and $19 \mathrm{wt} \%$, respectively. In addition, samples LA-07 and LA-09 are dominated by the fraction $125-250 \mu \mathrm{m}$ ranging between 31 and $40 \mathrm{wt} \%$, respectively. The finest fraction $(<63 \mu \mathrm{m})$ is the least represented and does not exceed $20 \mathrm{wt} \%$ except in sample LA01 with values reaching 27 wt $\%$.

\subsection{Geochemistry}

The results of the geochemical analyses are presented in Table 2. TOC values are generally very low for all samples. The maximum TOC content is observed in sample DJB-10 with 0.9 wt $\%$, however, in general, TOC fluctuates from 0.07 (LA-04) to $0.5 \%$ (LA-01). MINC values are relatively low in the inner part of the lagoon and increase towards the outer part. Minimum and maximum MINC values are reached respectively at station LA-04 and LA-09 with 3.62 and 9.04 wt\%. The HI values do not fluctuate significantly among samples varying from 213 (LA-07) to $373 \mathrm{mg} \mathrm{HC} / \mathrm{g}$ TOC (LA-01), whereas, OI oscillates from 298 (LA-10) to $823 \mathrm{mg} \mathrm{CO} 2 / \mathrm{g}$ TOC (LA-06). These data was used in this study to determine the provenance of the sedimentary OM (Fig. 4): (i) HI vs OI plot is widely used to represent the origin of the sedimentary OM, however the plots are out of the different delimited areas for the kerogen type. (ii) $\mathrm{HI}$ vs $\mathrm{T}_{\max }$ plot indicates a kerogen type IIb (Delvaux et al. 1990). (iii) S2 vs TOC plot confirms the type II kerogen (Langford and Blanc-Valleron 1990).

Total nitrogen (TN) contents are low and do not exceed $0.088 \mathrm{wt} \%$ (LA-10) with some samples being below the detection limit (LA-03, LA-04 and LA-06). Total carbon contents have similar trends as the MINC, with a maximum of $9.074 \mathrm{wt} \%$ for sample LA-10 and a minimum of 3.583 wt\% for sample LA-04. Total hydrogen content is relatively high in sample LA-01 with $1 \mathrm{wt} \%$ but low for all other samples, fluctuating from $0.066 \%$ (LA-04) to $0.288 \%$ (LA-10). Stable carbon isotopic composition of $\mathrm{OM}$ is similar for all samples, ranging between - 16.7\%o (LA-04) to $-14.6 \%$ (LA-09).

\subsection{Water parameters}

Concentration and $\mathrm{CF}$ of major and minor elements in seawater are shown in Tables 3 and 4. In general the lowest concentrations of major elements are found at station LA10. Sodium and magnesium have respectively concentrations of 11,869 and $1399 \mathrm{mg} / \mathrm{L}$. Sulfur has also a relatively 


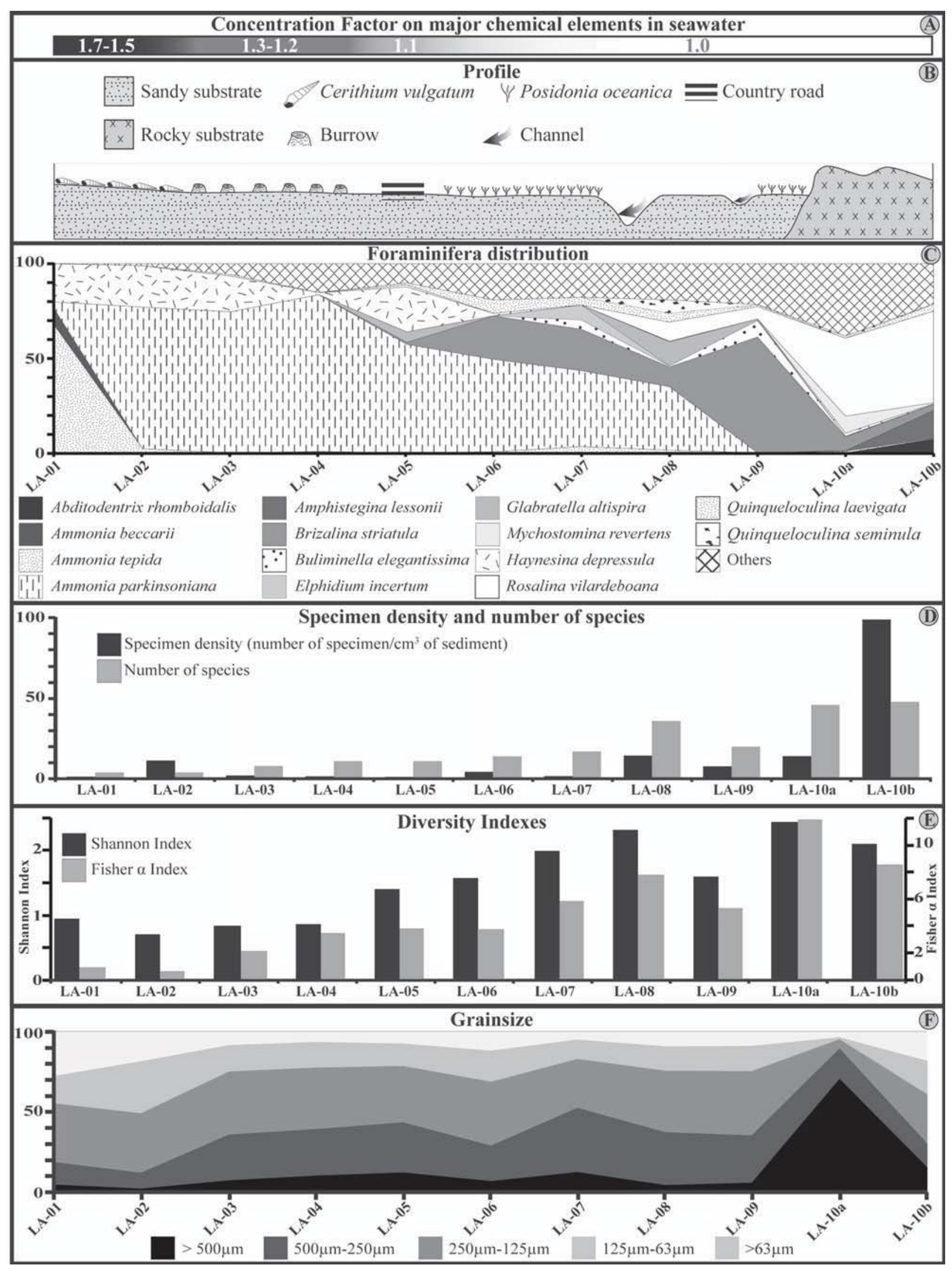


4Fig. 3 a Concentration factor of major elements in seawater along the transect. b Profile of Djerba lagoon. c Distribution of the ten dominant foraminiferal species in the lagoon (in \%). d Specimen density and number of species. e Diversity indexes. f Grain size distribution of surface sediments

low concentration with $945 \mathrm{mg} / \mathrm{L}$ followed by $\mathrm{Ca}$ and $\mathrm{K}$ with respectively 462 and $442 \mathrm{mg} / \mathrm{L}$. Strontium has the lowest concentration at station LA-10 with only $8.4 \mathrm{mg} / \mathrm{L}$. An almost two-fold increase in major element concentrations was observed from the external (LA-10) to the internal parts of the lagoon (LA-01). However, the concentration of major elements in seawater is relatively similar in stations LA-06 and LA-10 and their CF is equal to 1 . For samples between LA-01 to LA-05, the CF did not exceeded 1.8 for all major elements.

Concentration factors of most minor elements in the seawater are different than those of major elements.
Generally, the CF of minor elements increased from station LA-10 to LA-01, with the exception of $\mathrm{Cd}(\mathrm{CF}=1)$, As (CF slightly decreasing from stations LA-10 and LA-01) and $\mathrm{Cr}(\mathrm{CF}<1.4$, except for station LA-05). Concentration factors of Li have similar trends as major elements. Silicon reaches its highest concentration factor at station LA-01, with a value of 23.6. Concentration factors of $\mathrm{P}, \mathrm{Al}$, $\mathrm{Fe}$ and Mn fluctuate from station LA-10 to LA-01, they reach maximum factors at station LA-05 and LA-01, respectively.

\subsection{Living foraminifera and multivariate analyses}

Living foraminiferal diversity is relatively high in the lagoon. Ninety-six living species have been identified (Online Resource 1). Fourteen species ( $>7 \%$ of relative

Table 2 Rock Eval data, $\mathrm{C} / \mathrm{H} / \mathrm{N}$ elemental content in surface sediment and stable carbon isotopic composition of organic matter

\begin{tabular}{|c|c|c|c|c|c|c|c|c|c|c|c|c|c|}
\hline Sample & $\begin{array}{l}\text { TOC } \\
(\mathrm{wt} \%)\end{array}$ & $\begin{array}{l}\text { MINC } \\
\text { (wt } \%)\end{array}$ & $\begin{array}{l}\mathrm{HI}(\mathrm{mg} \\
\mathrm{HC} / \mathrm{g} \\
\mathrm{TOC})\end{array}$ & $\begin{array}{l}\mathrm{OI}(\mathrm{mg} \\
\mathrm{CO}_{2} / \mathrm{g} \\
\mathrm{TOC})\end{array}$ & $\begin{array}{l}\mathrm{T}_{\max } \\
\left({ }^{\circ} \mathrm{C}\right)\end{array}$ & $\begin{array}{l}\mathrm{S} 1 \\
(\mathrm{mg} \\
\mathrm{HC} / \mathrm{g})\end{array}$ & $\begin{array}{l}\mathrm{S} 2 \mathrm{a} \\
(\mathrm{mg} \\
\mathrm{HC} / \mathrm{g})\end{array}$ & $\begin{array}{l}\mathrm{S} 2 \mathrm{~b} \\
(\mathrm{mg} \\
\mathrm{HC} / \mathrm{g})\end{array}$ & S3 & $\begin{array}{l}\text { Total } \\
\text { nitrogen } \\
\text { (wt } \%)\end{array}$ & $\begin{array}{l}\text { Total } \\
\text { carbon } \\
\text { (wt } \%)\end{array}$ & $\begin{array}{l}\text { Total } \\
\text { hydrogen } \\
\text { (wt\%) }\end{array}$ & $\delta^{13} \mathrm{C}(\%)$ \\
\hline LA-01 & 0.5 & 4.93 & 373 & 379 & 423 & 0.02 & 1.87 & 0 & 1.9 & 0.071 & 5.688 & 1 & -15.153 \\
\hline LA-02 & NA & NA & NA & NA & NA & NA & NA & NA & NA & 0.059 & 4.618 & 0.181 & -15.395 \\
\hline LA-03 & 0.08 & 4.12 & 346 & 738 & 425 & 0.01 & 0.28 & 0 & 0.61 & 0 & 3.927 & 0.074 & -16.062 \\
\hline LA-04 & 0.07 & 3.62 & 370 & 682 & 425 & 0 & 0.27 & 0 & 0.5 & 0 & 3.583 & 0.066 & -16.686 \\
\hline LA-05 & 0.11 & 4.52 & 281 & 564 & 427 & 0 & 0.32 & 0 & 0.63 & 0.013 & 4.518 & 0.083 & -16.612 \\
\hline LA-06 & 0.08 & 4.17 & 325 & 823 & 426 & 0 & 0.25 & 0 & 0.64 & 0 & 4.393 & 0.08 & -16.219 \\
\hline LA-07 & 0.09 & 5.57 & 213 & 697 & 427 & 0 & 0.19 & 0 & 0.62 & 0.026 & 7.782 & 0.148 & -16 \\
\hline LA-08 & 0.29 & 9.04 & 250 & 394 & 433 & 0 & 0.73 & 0 & 1.15 & 0.028 & 8.867 & 0.158 & -15.63 \\
\hline LA-09 & 0.39 & 8.73 & 238 & 352 & 427 & 0 & 0.92 & 0 & 1.36 & 0.031 & 8.975 & 0.172 & -14.578 \\
\hline LA-10 & 0.9 & 8.36 & 348 & 298 & 417 & 0.02 & 3.13 & 0 & 2.68 & 0.088 & 9.074 & 0.288 & -16.039 \\
\hline
\end{tabular}
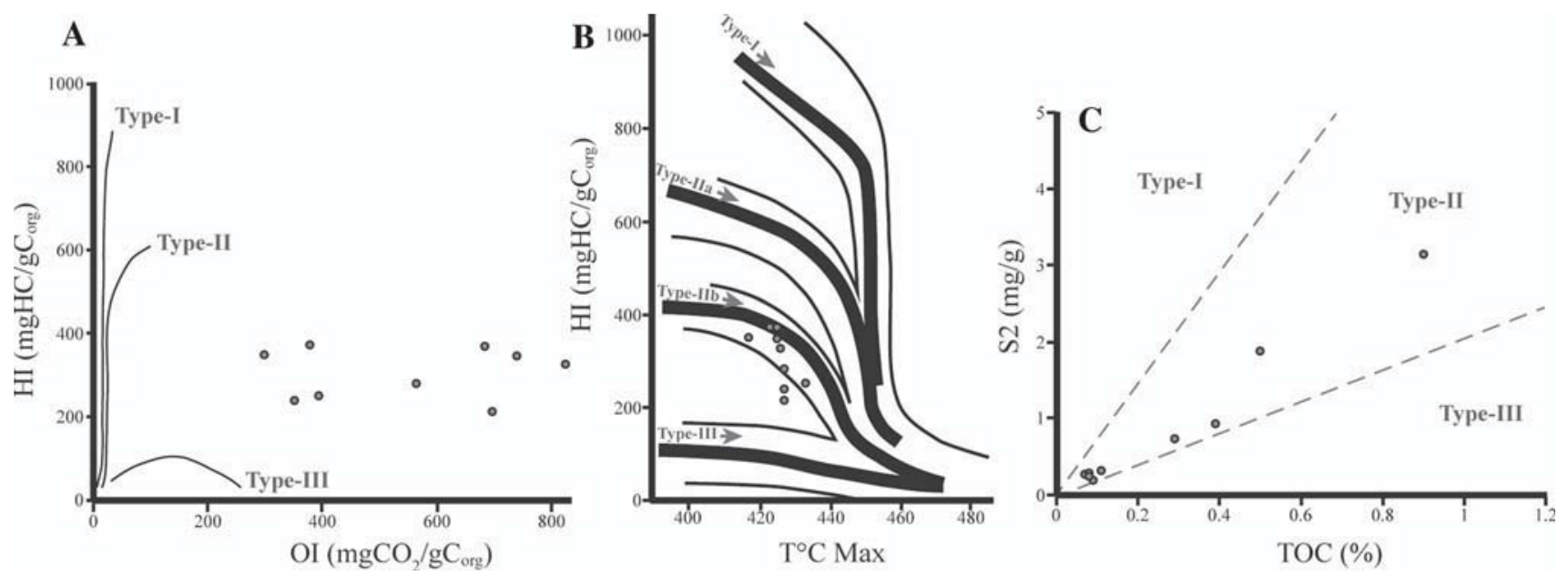

Fig. 4 Kerogen type of the sedimentary organic matter based on Rock-Eval data. a $\mathrm{HI}\left(\mathrm{mg} \mathrm{HC}_{\mathrm{g} \mathrm{C}}\right.$ org) versus OI ( $\mathrm{mg} \mathrm{CO}_{2} / \mathrm{g} \mathrm{C}_{\text {org }}$ ). b $\mathrm{HI}(\mathrm{mg} \mathrm{HC}$ $\left.\mathrm{g} \mathrm{C}_{\text {org }}\right)$ versus $\mathrm{T}_{\max }\left({ }^{\circ} \mathrm{C}\right) . \mathbf{c ~ S} 2(\mathrm{mg} / \mathrm{g})$ versus TOC $(\%)$ 
Table 3 Concentration $(\mathrm{mg} / \mathrm{L})$ and concentration factor of major elements in seawater samples

\begin{tabular}{|c|c|c|c|c|c|c|c|c|c|c|c|c|}
\hline Sample no & $\mathrm{Na}(\mathrm{mg} / \mathrm{L})$ & $\mathrm{CF}_{\mathrm{Na}}$ & $\mathrm{Mg}(\mathrm{mg} / \mathrm{L})$ & $\mathrm{CF}_{\mathrm{Mg}}$ & $\mathrm{S}(\mathrm{mg} / \mathrm{L})$ & $\mathrm{CF}_{\mathrm{S}}$ & $\mathrm{K}(\mathrm{mg} / \mathrm{L})$ & $\mathrm{CF}_{\mathrm{K}}$ & $\mathrm{Ca}(\mathrm{mg} / \mathrm{L})$ & $\mathrm{CF}_{\mathrm{Ca}}$ & $\mathrm{Sr}(\mathrm{mg} / \mathrm{L})$ & $\mathrm{CF}_{\mathrm{Sr}}$ \\
\hline LA-01 & $>20,654$ & 1.7 & $>2130.6$ & 1.5 & 1427.3 & 1.5 & $>785.19$ & 1.8 & $>771.62$ & 1.7 & 12.23 & 1.5 \\
\hline LA-02 & $>20,012$ & 1.7 & 2100.5 & 1.5 & 1412.5 & 1.5 & $>754.82$ & 1.7 & $>742.92$ & 1.6 & 11.94 & 1.4 \\
\hline LA-03 & 15,035 & 1.3 & 1698 & 1.2 & 1182.2 & 1.3 & 547.76 & 1.2 & 553.03 & 1.2 & 9.79 & 1.2 \\
\hline LA-04 & 14,073 & 1.2 & 1617 & 1.2 & 1134.2 & 1.2 & 512.26 & 1.2 & 524.95 & 1.1 & 9.41 & 1.1 \\
\hline LA-05 & 12,980 & 1.1 & 1505.6 & 1.1 & 1068.6 & 1.1 & 468.38 & 1.1 & 494.71 & 1.1 & 8.93 & 1.1 \\
\hline LA-06 & 12,194 & 1.0 & 1418.2 & 1.0 & 948.14 & 1.0 & 449.82 & 1.0 & 464.46 & 1.0 & 8.48 & 1.0 \\
\hline LA-07 & 12,166 & 1.0 & 1414.9 & 1.0 & 955.79 & 1.0 & 453.78 & 1.0 & 468.96 & 1.0 & 8.42 & 1.0 \\
\hline LA-08 & 11,920 & 1.0 & 1400.2 & 1.0 & 943.04 & 1.0 & 443.69 & 1.0 & 459.64 & 1.0 & 8.34 & 1.0 \\
\hline LA-09 & 11,894 & 1.0 & 1399.8 & 1.0 & 943.15 & 1.0 & 446.9 & 1.0 & 474.75 & 1.0 & 8.48 & 1.0 \\
\hline LA-10 & 11,869 & 1.0 & 1399.2 & 1.0 & 945.16 & 1.0 & 442.67 & 1.0 & 462.23 & 1.0 & 8.4 & 1.0 \\
\hline
\end{tabular}

abundance on at least one station) represent at least $60 \%$ of all living specimens (LA-10a). The distribution of the 14 most dominant species changes significantly along the transect (Figs. 3, 5). The inner part of the lagoon is dominated by Haynesina depressula and Ammonia spp., although the species Ammonia tepida is only present at stations LA-01 and LA-02. Brizalina striatula, Glabratella altispira, Mychostomina revertens become progressively more abundant from station LA-05 to station LA-10, although in variable amounts. The abundance of Rosalina vilardeboana increases significantly from station LA-05 to LA-06 and is especially abundant at station LA-10b. $A b$ ditodentrix rhomboidalis and Amphistegina lessonii are present, but only dominant in station LA-10. Specimen density and number of species per station have similar trends along the transect (Figs. 3, 5). They are relatively low in the inner part of the lagoon, especially at station LA01 (1.3 specimen $/ \mathrm{cm}^{3}$ of sediment and only 4 living species). The density of living foraminifera shows an increasing trend from station LA-01 to LA-10. Some fluctuation in abundances are observed at station LA-02 and LA-09, station LA-10b has a very high living specimen density, with 99 specimens $/ \mathrm{cm}^{3}$ of sediment. The number of species shows a continuous increase trend from station LA-01 to LA-10, except samples LA-09 and LA-10a, which show a slight decrease in comparison to station LA08. Sample LA-10b shows the highest species number with 48 species. Species richness varies from 4 to 48 . The Shannon Index $\left(\mathrm{H}^{\prime}\right)$ reaches lowest value on station LA-02 with 0.69 and has the highest score of 2.42 on station LA10 (Fig. 3). The Fisher $\alpha$ Index displays values between 0.58 and 11.86 . Both diversity Indexes show similar trends with the number of species per stations (Online Resource 1) and increase from station LA-02 to LA-10 with a marked decrease on station LA-09.

Based on the Bray-Curtis Similarity and n-MDS plots, two clusters are identified in the dendrogram. Cluster 1 groups samples LA-01 to LA-07 with Ammonia parkinsoniana $(57.51 \%)$, Haynesina depressula (19.45\%) and Elphidium incertum $(7.31 \%)$ as dominant species and is interpreted as representing the internal part of the lagoon. Cluster 2 groups samples LA-08, LA-09, LA-10b and LA$10 \mathrm{~b}$ representing the external parts of the lagoon with Brizalina striatula (21.09\%), Rosalina vilardeboana (18.37\%), and Rosalina bradyi $(7.12 \%)$ as the dominant species.

\section{Discussion}

\subsection{Impact of water parameters on the marine flora and macrofauna}

Water parameters are important factors controlling the distribution of the flora and fauna in the marine environment (Ruivo 1973). In coastal regions, the water parameter that has a major impact on the distribution and density of flora and fauna is salinity (e.g. Bulger et al. 1993; Montague and Ley 1993; Lamptey and Armah 2008). Unfortunately, during the sampling campaign, we were not equipped to record salinity measurements (e.g., with electrical conductivity meter, refractometer for seawater, seawater density meter). Therefore, in the present study, major elements are used to estimate salinity in the Djerba lagoon. A clear increase in the concentration of major chemical elements from the open sea towards the internal part of the lagoon was observed (Fig. 3). Based on CF the lagoon can be divided into two parts: (i) an external part close to the open sea characterized by normal saline seawater with CF $\leq$ 1. (LA-06, LA-07, LA-08, LA-09 and LA-10). (ii) An internal part that can be considered as hypersaline with a salinity that can be estimated to be around 1.5 times higher than normal seawater conditions (LA-01, LA-02, LA-03, LA-04 and LA-05). However, the seawater sampling was performed during the rising tide and it has to be taken in account that the current probably influences the 


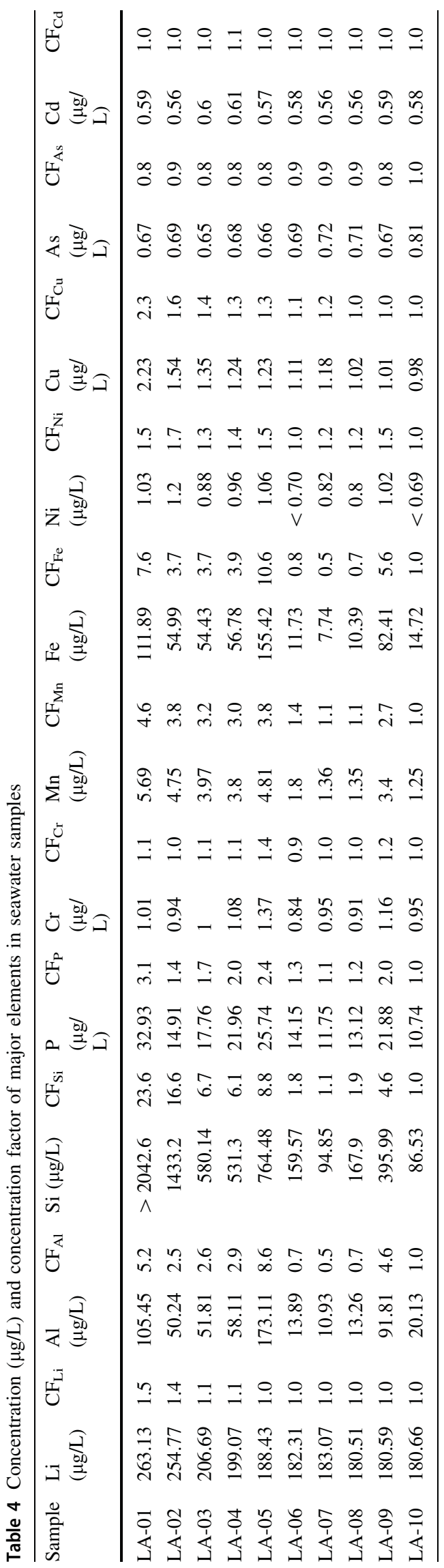

internal part of the lagoon close to the channel. Stations LA-06 and LA-07 can be regarded as transitional stations where the salinity (i.e. CF) can significantly fluctuate depending to the tide level.

The concentrations of major elements in the internal part of the lagoon are directly linked to the arid climate. This is especially true in the summer, when increased evaporation may increase salinity to hypersaline values (Kjerfve et al. 1996). Reduced seawater exchange between the internal part of the lagoon and the open sea may also be responsible for the hypersaline conditions as this is characteristic of choked lagoons with longer flushing times (Kjerfve 1994). The entrance of the lagoon may act as a dynamic filter significantly reducing the strength of tidal current and thus, seawater flow exchange toward the inside of the lagoon (Kjerfve 1994). In addition, the arched morphology of the channel may contribute to decrease the strength of the tidal current. This difference in the tidal current strength is expressed by the presence of moving sand banks (Fig. 2) between the lagoon entrance and the sharp bend of the lagoon.

A relationship exists between the $\mathrm{CF}$ and the $P$. oceanica seagrass meadow distribution inside the lagoon of Djerba. Posidonia oceanica is present only in areas where the CF does not exceed 1, although $P$. oceanica is absent in two stations (LA-08 and LA-10). In the case of station LA10 the rocky sea floor may prevent the roots of P. oceanica from colonizing the substrate, and in case of LA- 08 ( $>10 \mathrm{~cm}$ of the water depth) the very shallow water conditions may prevent the development and vertical growth of $P$. oceanica leaves.

Several studies demonstrated the sensitivity of $P$. oceanica to hypersaline conditions (Fernández-Torquemada and Sánchez-Lizaso 2005; Gacia et al. 2007; Sanchez-Lizaso et al. 2008). Brine discharges from desalination plants may increase the salinity of seawater and have a negative impact on P. oceanica meadows (e.g., Platja de Mitjorn on the Island of Formentera; Alicante in Spain) (Fernández-Torquemada et al. 2005; Gacia et al. 2007). Laboratory experiments have demonstrated that when seawater salinity exceeds $39.1 \mathrm{psu}$, marine vegetation mortality increases, while at 45 psu, $50 \%$ of the marine vegetation died within 15 days. However, $P$. oceanica is able to recover to normal growth when exposed to short hypersaline episodes (Fernández-Torquemada and Sánchez-Lizaso 2005).

Google Earth is an efficient tool to observe landscape evolution through time. Satellite images of Djerba lagoon, dating back to July 10th 2003, are available on Google Earth (https://www.google.com/earth/) where the distribution of Posidonia oceanica is clearly visible on satellite images. The comparison of images from 2003 with the present distribution of $P$. oceanica suggests no spatial/ 

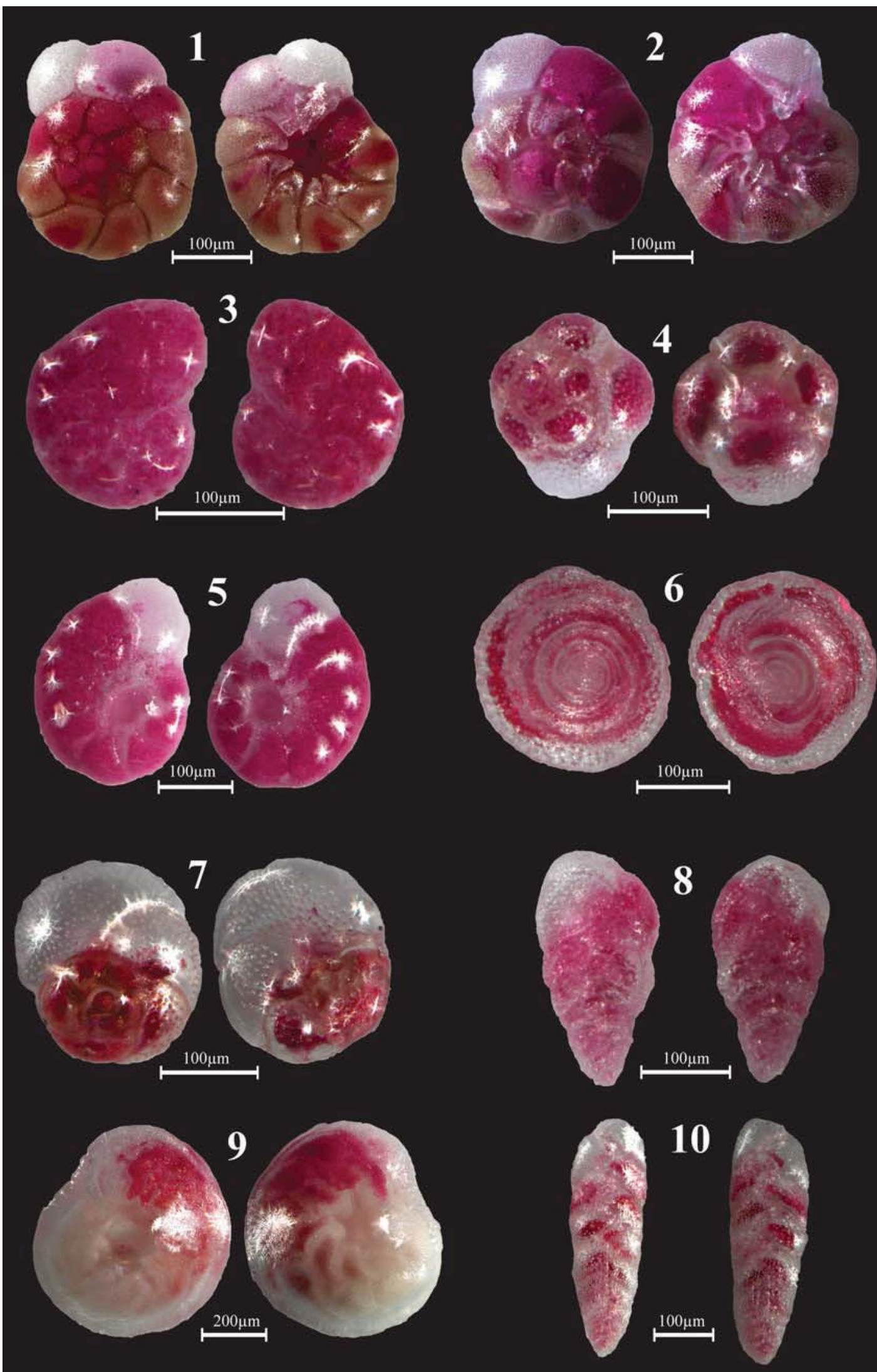
4Fig. 5 Pictures of living (stained) foraminifera: 1 Ammonia tepida (Cushman 1926); 2 Ammonia parkinsoniana (d'Orbigny 1839); 3 Elphidium incertum (Williamson 1858); 4 Glabratella altispira Buzas (Smith and Beem 1977); 5 Haynesina depressula (Walker and Jacob 1798); 6 Mychostomina revertens (Rhumbler 1906); 7 Rosalina vilardeboana (d'Orbigny 1839); 8 Abditodentrix rhomboidalis (Millett 1899); 9 Amphistegina lessonii (d'Orbigny in Guérin-Méneville 1832); 10 Brizalina striatula (Cushman 1922)

temporal variation and no seasonal effects. This observation indicates that the salinity of the Djerba Lagoon has not changed since 2003.

If the hypersaline environment is not favorable for $P$. oceanica, it may possibly provide a suitable ecological niche for other marine macro-organisms, such as $C$. vulgatum. This marine gastropod is very common along the Mediterranean Sea coast in shallow water marine ecosystems. The diet of this gastropod consists of diatoms and epibenthic microalgae (Nicolaidou and Nott 1999). Hypersaline conditions can be considered as an important stressor on marine organisms leading to a decrease in biodiversity, coupled with a reduced competition among marine organisms. Well-adapted and/or stress-tolerant organisms to natural fluctuations in environmental conditions can thus proliferate and dominate specific ecological niches, as $C$. vulgatum does in the innermost parts of the lagoon.

\subsection{Organic matter: origin and trophic state}

Organic matter is an essential food resource in marine environments and can also impact faunal and/or microfaunal distribution (e.g., Whitlatch 1981; Mojtahid et al. 2009). The amount and the origin of this food resource allows for better understanding of ecological processes in marine environments (e.g., Whitlatch 1981; Lopez and Levinton 1987) in addition to providing information on trophic resources.

Rock-Eval pyrolysis can be successfully used in environmental studies to determine the type of kerogen which indicates the origin of the OM. Type I kerogen is indicative of lacustrine environments, Type II kerogen of marine environments and type III of terrestrial environments (Espitalié et al. 1985). However, some study differentiate the Type IIa kerogen (marine) and Type IIb (mixed marine/ terrestrial) (e.g., Delvaux et al. 1990). Some limitations on Rock-Eval pyrolysis exist due to the low TOC content and where $\mathrm{HI}$ and OI should be interpreted with caution. Below $0.3 \%$ of TOC, a very limited amount of hydrocarbons can be produced which may induce low S1 and S2 peaks and form a wide gentle hump (Nunez-Betelu and Baceta 1994). In addition, values lower than $0.2 \mathrm{mg} \mathrm{HC} / \mathrm{g}$ sediment (S2 peak) may influence on $T_{\max }$ because the $\mathrm{S} 2$ peak becomes broad and low and hen the top of the peak cannot be accurately defined (Nunez-Betelu and Baceta 1994). The classical HI versus OI graph prevents a precise determination of the kerogen type (Fig. 4) because of the high OI values. Adsorption of $\mathrm{CO}_{2}$ is possibly induced by low TOC content in the sediments (Table 2) (Nunez-Betelu and Baceta 1994). In addition high carbonate mineral content increases the OI during the heating process of Rock-Eval analysis (Katz 1983) and may therefore represent serious limitations in the interpretation of the OM content.

The graphs S2 vs TOC and HI vs $\mathrm{T}_{\max }$ (Fig. 4) indicate that the OM composition is relatively homogenous along the lagoon of Djerba, and is mainly composed by type II kerogen. This kerogen type reflects a mix marine and terrestrial OM origin (Langford and Blanc-Valleron 1990; Delvaux et al. 1990). The type II kerogen is mostly composed by amorphous kerogen (e.g. planktonic material) and exinite (e.g. pollen, cuticle of leave and herbaceous plants). This mixed provenance of OM can be easily explained: in a coastal environment, planktonic material can be carried inside the lagoon by tidal currents, while the terrestrial OM origin is due to the presence of vegetation such as date palm trees on the western shore of the lagoon of Djerba. Organic matter can also come from the seagrass $P$. oceanica. This seagrass species presents similarities with land plants as it possesses cuticles and contains a high amount of cellulose (Nunez-Betelu and Baceta 1994; Khiari et al. 2010). Stable carbon isotope composition signal of $\mathrm{OM}$ from surface sediment correlates well with land plants and with $P$. oceanica. Enriched $\delta^{13} \mathrm{C}_{\mathrm{OM}}$ values $(>-18.5 \%)$ is typical for C4 land plants (Smith and Epstein 1971; Hedges et al., 1997). The $\delta^{13} \mathrm{C}_{\mathrm{OM}}$ of $P$. oceanica ranges from -19.7 to $-10.8 \%$ (Cooper and DeNiro 1989; Vizzini et al. 2002; Lepoint et al. 2003; Vizzini et al. 2003), which corresponds to $\delta^{13} \mathrm{C}_{\mathrm{OM}}$ values measured inside the lagoon of Djerba (Table 2).

The relatively high TOC content at station LA-10 (Table 2) can be explained by the algae carpet which traps the sediment, however, we cannot exclude a contribution of OM from the beachrock itself. Strasser et al. (1989) noticed organic compounds (e.g. algae, roots residue) in the beachrock from Bahiret el Biban (southeastern Tunisia). In addition, Vousdoukas et al. (2007) noticed OM associated with microbial structures in the beachrock. Environmental conditions in station LA-01 are extreme (high salinity coupled with high water temperature) and the TN content is relatively high in comparison to the other stations (Table 2). As a nutrient, nitrogen and phosphorus can influence the productivity of microalgae and increase the TOC content in the sediments, hence creating eutrophic conditions (Nixon 1995; Taylor et al. 1995). Following Smith (2003), the concentration in total phosphorus on station LA-01 (Table 4) is indicative of a very high nutrient 
pollution level ( $>31 \mu \mathrm{g} / \mathrm{L}$ of total phosphorus) for a coastal marine ecosystem and thus contribute probably to form eutrophic conditions at this station. High nutrient pollution level together with high sedimentary OM content indicate a high primary productivity which is the definition of eutrophication (Nixon 1995). High primary productivity may explain the high density of $C$. vulgatum as it provides an ideal food source for this gastropod. In contrast, low TOC content in the rest of the lagoon (LA-03 to LA-09) (Table 2) may possibly be related to the coarse sediment present in the lagoon. Coarse sediment may allow better oxygen diffusion into the sediments, promoting mineralization of OM and leading to the decrease of TOC content (Tyson 1995). Despite these low values (except for stations LA-01 and LA-10), the TOC content shows a consistent gradient in the Djerba lagoon probably due to the constant OM flux from tidal currents. However, we also suggest a possible ecological link between OM content and $P$. oceanica meadow distribution. During its life cycle, $P$. oceanica, regenerates its leafs (Ott 1980) and leaf litter represents a significant $\mathrm{OM}$ source laying on the surface sediment (Romero et al. 1992; Lepoint et al. 2006).

\subsection{Benthic foraminifera as bioindicators}

Foraminifera are good bioindicators that can provide valuable information about environmental conditions (e.g. Alve 1991; Kaiho 1994; Hallock et al. 2003; Mateu-Vicens et al. 2010; Dimiza et al. 2016). Changes in foraminiferal assemblages can be related to changes of environmental physiochemical parameters (e.g., pH, dissolved oxygen), $\mathrm{OM}$, or substrate type. Living benthic foraminiferal assemblages change significantly within the Djerba lagoon (Fig. 3) based on variations in physiochemical parameters, tidal currents and seagrass distribution. Previous studies demonstrated that some foraminiferal species are sensitive to variations in grain size (e.g., Murray 2006). However in the case of the study area, grain size is fairly homogeneous within the entire lagoon and its possible influence on foraminiferal assemblages can be excluded.

Living benthic foraminiferal assemblages suggest a division of the lagoon into two parts (Fig. 6) separated by the channel, acting as a natural barrier between the internal and the external parts of the lagoon. The channel represents a dynamic environment due to the action of tidal currents that have shaped its present morphology. The channel also acts as a preferential flowing path for the tidal flow, thus reducing tidal energy towards the internal lagoon preventing the transport of foraminifera between internal and external parts of the lagoon.

Ammonia parkinsoniana is one of the most abundant species along a large part of the lagoon and is especially dominant in the internal part. Ammonia parkinsoniana can
Fig. 6 Living foraminiferal distribution in the Djerba lagoon based on the statistical treatment. a Profile of Djerba lagoon with delimitation of the internal and external parts. b Hierarchical Cluster Analysis based on Bray-Curtis similarity matrix of the living (stained) foraminifera of Djerba lagoon. c Non-metric MultiDimensional Scaling (nMDS) plot obtained from Bray-Curtis (dis)similarity matrix of living benthic foraminifera of the Djerba lagoon

be considered as stress tolerant because it is a dominant species in the NorthwesternGulf of Mexico under highly variable environmental condition (Gupta et al. 1996 and references therein). In addition, in Puerto Rican bays and lagoons, this species is abundant in fine-grained, polluted and organic-rich sediments (Gupta et al. 1996 and references therein). Ammonia parkinsoniana is also abundant in the Bizerte lagoon and this species is common in transitional environments under seawater influence (Martins et al. 2016) such as Djerba lagoon.

The hypersaline environment directly impacts benthic foraminiferal density in the internal part of the lagoon where species numbers is lower than in its external part. The dominance of Ammonia tepida reflects the extreme hypersaline conditions and high water temperature in the internal edge of the lagoon. In particular, A. tepida was observed in shallow marine environments and lagoons (Frontalini et al. 2009) and is tolerant to thermal pollution. Ammonia spp. is also known to be very tolerant to hypersaline environments (Walton and Sloan 1990; Murray 2006). Another dominant species in the hypersaline internal part of the lagoon is $H$. depressula. This species is known to colonize sandy substrate in inner shelf environments and is tolerant to brackish water intolerant to salinity higher than 50 psu (Murray 2006). However, this species was identified in several locations along the Gulf of Saros (Turkey) in environments where salinity reached over 50 psu (Bassler-Veit et al. 2013). Based on the concentration factor and the normal seawater salinity in the southern coast of Tunisia ( 37 psu) (Béranger et al. 2004), the present study suggests that salinity can exceed 55 psu in the part of the lagoon where $H$. depressula is dominant and confirms the ecological tolerance of this species to high salinity.

Elphidium incertum is relatively abundant in the internal part of the lagoon (Online Resource 1). It is described as uncommon in bays, marshes and in lagoon barriers ( $\mathrm{Ph}$ leger 1965). In the northern Gulf of Mexico, E. incertum is typical for brackish inlet-influenced outer lagoon environments (Otvos 1985). This species is less abundant than Ammonia spp. in the internal part of Djerba lagoon and its presence is probably not directly related to the salinity conditions like $H$. depressula. Elphidium incertum was also observed in the inner part of Flensburg Fjord (SW Baltic 


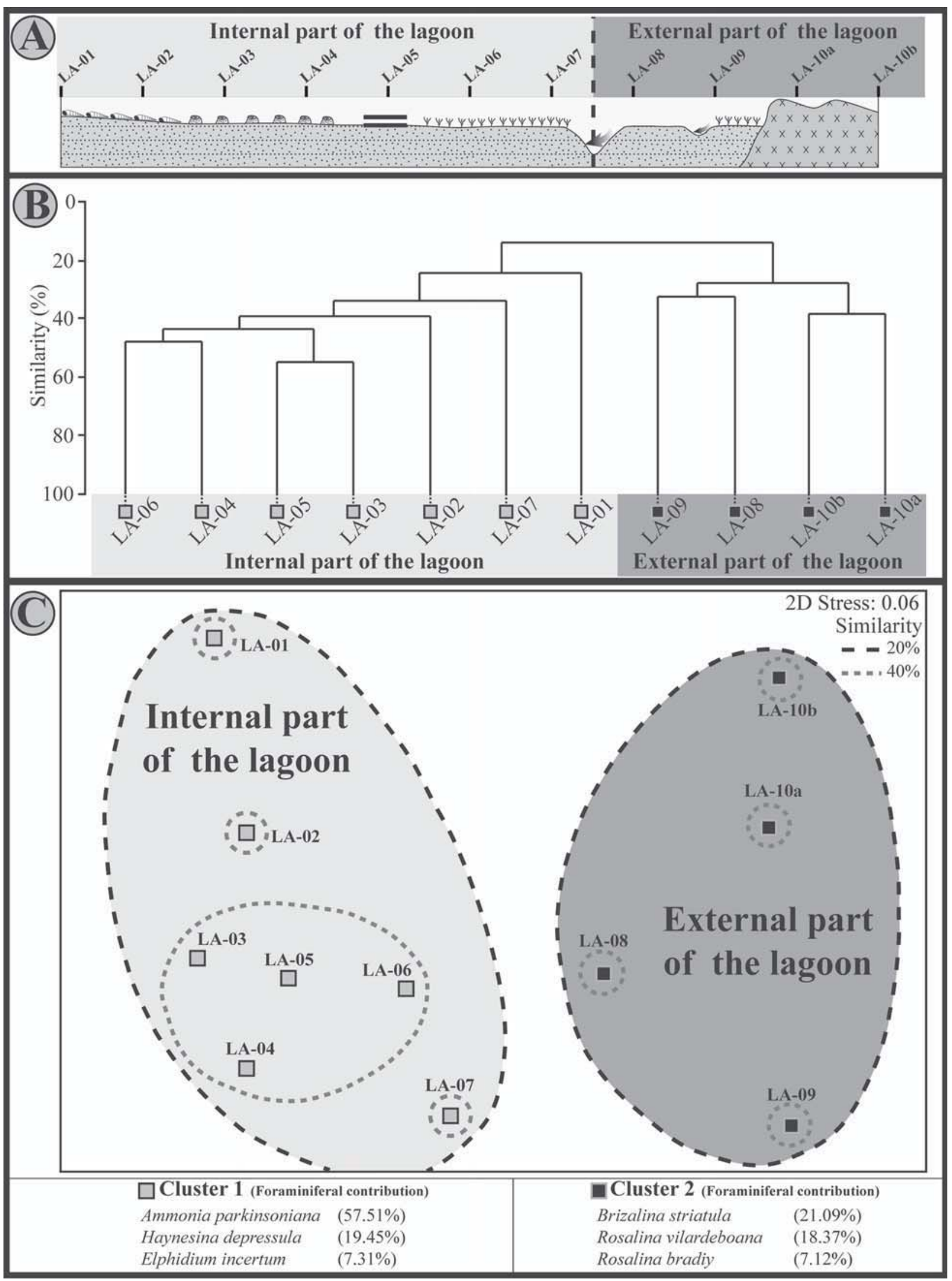


Sea), where high organic matter content in the muddy sediment provides ideal living conditions (Polovodova et al. 2009). Murray (2006), indicates that E. incertum prefers shallow infaunal habitats in sandy substrates, with high oxygen positively impacting on its reproduction. In the Djerba lagoon, the abundances of E. incertum correlate with burrows and seagrass in the internal lagoon. Burrows from macrofaunal activity increase oxygenation in the first centimeters of sediment, and $P$. oceanica, as a marine plant, supplies oxygen through photosynthesis, providing ideal conditions for E. incertum to develop.

A strong correlation exists between the presence of $B$. striatula and the distribution of the seagrass $P$. oceanica. The genus Brizalina has an infaunal mode of life and has specific resistance to oxygen depletion in the environment (Murray 2006). Generally, taxa, which are tolerant to low oxygen conditions are typical of muddy substrates that can accumulate high amounts of organic matter (Van der Zwaan et al. 1999). In the Djerba lagoon, the presence of $B$. striatula and its preference for oxygen-depleted environments does not match with the observed low OM content and the coarse sediments. However, low oxygen tolerant species and low oxygen conditions can be associated to seagrass decaying in sediments (Mateu-Vicens et al. 2014). In addition, the trophic preference of brizalinids for organic detritus (Murray 2006) suggests that remains of P. oceanica could be a potential food resource.

The abundance of the epifaunal Rosalina vilardeboana and Amphistegina lessonii at station LA-10 can be explained by the hard substratum (Murray 2006). The beachrock located in the eastern part of the lagoon is an ideal environment for their development. The genus Amphistegina is widely used to assess water quality because of its fast response to environmental changes (e.g. water temperature) (e.g. Emrich et al. 2017; de Freitas Prazeres et al. 2012; Hallock et al. 2003). The abundance of Amphistegina spp. and its sensitivity to water quality deviating from normal conditions (e.g., Hallock et al. 2003) confirms the normal marine conditions at the external part of the lagoon. Water quality influencing the development of $R$. vilardeboana are poorly described in the literature. However this species was described as opportunistic in a benthic foraminiferal culturing system (Hintz et al. 2004). Erginal et al. (2013) describe this species as an indicator of shallow water. However, the present study confirms that $R$. vilardeboana shows affinity for substrates with more abundant organic carbon and is influenced by the distribution of Posidonia oceanica (Buosi et al. 2012).

The changes in the living foraminiferal assemblages within the lagoon is the consequence of an important environmental zonation due to changes in salinity, water depth, presence/absence of seagrass and type of substrate along a $2 \mathrm{~km}$ area. Biotic and abiotic changes reflect the transition from hypersaline conditions from the internal part of the lagoon to normal marine conditions in its external part.

\subsection{Is there an anthropogenic impact on the lagoon?}

The Gulf of Gabes is well known to be severely polluted by one of the main industrial phosphate treatment complex in Tunisia. Many studies have demonstrated a negative impact of this pollution on marine flora such as $P$. oceanica (e.g. El Zrelli et al. 2017), or on macrofauna like the coral Cladocora caespitosa (El Kateb et al. 2016). The geographic position of the Djerba lagoon, within the center of the touristic area of the Djerba Island, makes it particularly vulnerable to the pollution by tourist activities. Despite of human activities around the Djerba lagoon (e.g., tourism), only few signs of eutrophic conditions were noticed. High nutrient contents on station LA-01 were not clearly defined as anthropogenic origin. Urban sewage close to station LA01 could be one explanation for high phosphorus content (Gilabert 2001). However, remineralization of OM under warm temperatures carried at the station LA-01 could release phosphorus from the sediment (Nixon 1982) and induce eutrophic conditions. High heavy metal content in marine or terrestrial environments is generally interpreted as a sign of contamination by anthropogenic activities. In the case of the Djerba lagoon, the concentration of metal elements in the seawater is relatively low (Table 4). Concentration factors of minor elements are significantly different depending on the element. Processes can control trace metal concentrations in seawater, such as active biological processes, which can remove trace metals from seawater (Bruland and Lohan 2006). Redox cycling of metals can also influence trace metal concentrations in seawater (Morel and Price 2003). The cause of high CF for silicon (Table 4) on the station LA-01 is not clearly defined. However, the eutrophic state of this station is suspected as a possible factor for quartz solubility. In agreement with the biogeochemical cycle of Si (BasileDoelsch et al. 2005) siliceous sources in seawater are provide by silicate minerals of endogenous rocks. Quartz is one of the main substrate minerals in the Djerba lagoon. Several studies (Bennett and Siegel 1987; Bennett et al. 1988; Bennett 1991) show the influence of organic acid/compounds on the quartz solubility and quartz dissolution kinetics. Organic matter decay caused by eutrophic conditions probably releases dissolved organic acid/compounds in water and thus increase the solubility of quartz. However, further investigations are needed to confirm this hypothesis. A peculiar behavior of concentrate factors of some minor elements was noticed at station LA-05 (Table 4), corresponding geographically to the country 
road crossing the Djerba lagoon. This country road is used by tourists to cross the lagoon with vehicles. The increase in seawater of the concentration factors for $\mathrm{P}, \mathrm{Al}, \mathrm{Cr}, \mathrm{Fe}$ and $\mathrm{Mg}$ at the country road station (LA-05) is probably the result of intense tourist passage on this country road crossing the lagoon. In addition, the lowest living foraminiferal specimen density is reached when in close proximity to this road (Fig. 3). Although the road side site may be slightly impacted by tourism, our preliminary results suggest a minor anthropogenic impact in the Djerba lagoon.

\section{Conclusion}

The Djerba lagoon is a transitional environment from hypersaline to normal marine conditions. The high salinity in the inner lagoon is due to the shallow water depth combined with the arid climate (e.g., warm weather and high solar radiation). The variation in salinity has a direct impact on seagrass distribution and creates small-scale ecological niches for macro fauna in the internal part of the lagoon. A clear zonation in the distribution of living foraminiferal assemblages was noticed in the Djerba lagoon. A channel seems to act like a natural barrier, separating the internal and the external part of the lagoon. Based on these observations, the lagoon represents a unique ecosystem in the Djerba Island.

\section{References}

Alve, E. (1991). Benthic foraminifera in sediment cores reflecting heavy metal pollution in Sorfjord, western Norway. Journal of Foraminiferal Research, 21(1), 1-19.

Arfi, R. (1989). Annual cycles and budget of nutrients in Berre Lagoon (Mediterranean Sea, France). International Review of Hydrobiology, 74(1), 29-49.

Basile-Doelsch, I., Meunier, J. D., \& Parron, C. (2005). Another continental pool in the terrestrial silicon cycle. Nature, 433(7024), 399-402.

Bassler-Veit, B., Barut, I. F., Meric, E., Avsar, N., Nazik, A., KapanYeşilyurt, S., et al. (2013). Distribution of microflora, meiofauna, and macrofauna assemblages in the hypersaline environment of northeastern Aegean Sea coasts. Journal of Coastal Research, 29(4), 883-898.

Bellucci, L. G., Frignani, M., Paolucci, D., \& Ravanelli, M. (2002). Distribution of heavy metals in sediments of the Venice Lagoon: The role of the industrial area. Science of the Total Environment, 295(1), 35-49.

Ben-Ameur, W. B., de Lapuente, J., El Megdiche, Y., Barhoumi, B., Trabelsi, S., Camps, L., et al. (2012). Oxidative stress, genotoxicity and histopathology biomarker responses in mullet (Mugil cephalus) and sea bass (Dicentrarchus labrax) liver from Bizerte Lagoon (Tunisia). Marine Pollution Bulletin, 64(2), 241-251.

Bennett, P. C. (1991). Quartz dissolution in organic-rich aqueous systems. Geochimica et Cosmochimica Acta, 55(7), 1781-1797.
Bennett, P. C., Melcer, M. E., Siegel, D. I., \& Hassett, J. P. (1988). The dissolution of quartz in dilute aqueous solutions of organic acids at $25^{\circ} \mathrm{C}$. Geochimica et Cosmochimica Acta, 52(6), 1521-1530.

Bennett, P., \& Siegel, D. I. (1987). Increased solubility of quartz in water due to complexing by organic compounds. Nature, 326(6114), 684-686.

Béranger, K., Mortier, L., Gasparini, G. P., Gervasio, L., Astraldi, M., \& Crépon, M. (2004). The dynamics of the Sicily Strait: A comprehensive study from observations and models. Deep Sea Research Part II: Topical Studies in Oceanography, 51(4), 411-440.

Bouchet, V. M., Goberville, E., \& Frontalini, F. (2018). Benthic foraminifera to assess Ecological Quality Statuses in Italian transitional waters. Ecological Indicators, 84, 130-139.

Brahim, M., Atoui, A., Sammari, C., \& Aleya, L. (2014). Surface sediment dynamics along the eastern coast of Djerba Island (Gabes Gulf, Tunisia). Journal of African Earth Sciences, 92, $45-54$.

Bruland, K. W., \& Lohan, M. C. (2006). Controls of trace metals in seawater. The oceans and marine geochemistry, 6, 23-47.

Bulger, A. J., Hayden, B. P., Monaco, M. E., Nelson, D. M., \& McCormick-Ray, M. G. (1993). Biologically-based estuarine salinity zones derived from a multivariate analysis. Estuaries and Coasts, 16(2), 311-322.

Buosi, C., Châtelet, E. A. D., \& Cherchi, A. (2012). Benthic foraminiferal assemblages in the current-dominated Strait of Bonifacio (Mediterranean Sea). The Journal of Foraminiferal Research, 42(1), 39-55.

Callender, E. (2003). Heavy metals in the environment-Historical trends. In B.S. Lokkar (Ed.), Environmental geochemistry, H.D. Holland, K.K. Turekian (Eds.), Journal of treatise on geochemistry (pp. 67-106). Elsevier: Pergamon Oxford.

Chambouvet, A., Laabir, M., Sengco, M., Vaquer, A., \& Guillou, L. (2011). Genetic diversity of Amoebophryidae (Syndiniales) during Alexandrium catenella/tamarense (Dinophyceae) blooms in the Thau lagoon (Mediterranean Sea, France). Research in Microbiology, 162(9), 959-968.

Chouba, L., Kraiem, M., Njimi, W., Tissaoui, C. H., Thompson, J. R., \& Flower, R. J. (2007). Seasonal variation of heavy metals (Cd, $\mathrm{Pb}$ and $\mathrm{Hg}$ ) in sediments and in mullet, Mugil cephalus (Mugilidae), from the Ghar El Melh Lagoon (Tunisia). Transitional Waters Bulletin, 1(4), 45-52.

Cimerman, F., \& Langer, M. R. (1991). Mediterranean Foraminifera (Vol. 30, p. 118). Ljubljana, Dela Opera.

Clarke, K. R., \& Gorley, R. N. (2006). PRIMER v6: User Manual/ Tutorial. Primer-E: Plymouth.

Cooper, L. W., \& DeNiro, M. J. (1989). Stable carbon isotope variability in the seagrass Posidonia oceanica: evidence for light intensity effects. Marine Ecology Progress Series, 50(3), 225-229.

de Freitas Prazeres, M., Martins, S. E., \& Bianchini, A. (2012). Assessment of water quality in coastal waters of Fernando de Noronha, Brazil: Biomarker analyses in Amphistegina lessonii. Journal of Foraminiferal Research, 42(1), 56-65.

Dell'Anno, A., Mei, M. L., Pusceddu, A., \& Danovaro, R. (2002). Assessing the trophic state and eutrophication of coastal marine systems: a new approach based on the biochemical composition of sediment organic matter. Marine Pollution Bulletin, 44(7), 611-622.

Delpy, F., Pagano, M., Blanchot, J., Carlotti, F., \& Thibault-Botha, D. (2012). Man-induced hydrological changes, metazooplankton communities and invasive species in the Berre Lagoon (Mediterranean Sea, France). Marine Pollution Bulletin, 64(9), 1921-1932.

Delvaux, D., Martin, H., Leplat, P., \& Paulet, J. (1990). Geochemical characterization of sedimentary organic matter by means of 
pyrolysis kinetic parameters. Organic Geochemistry, 16(1-3), 175-187.

Dimiza, M. D., Triantaphyllou, M. V., Koukousioura, O., Hallock, P., Simboura, N., Karageorgis, A. P., et al. (2016). The Foram Stress Index: A new tool for environmental assessment of soft-bottom environments using benthic foraminifera. A case study from the Saronikos Gulf, Greece. Eastern Mediterranean. Ecological Indicators, 60, 611-621.

Dridi, S., Romdhane, M. S., \& Elcafsi, M. H. (2007). Seasonal variation in weight and biochemical composition of the Pacific oyster, Crassostrea gigas in relation to the gametogenic cycle and environmental conditions of the Bizert lagoon, Tunisia. Aquaculture, 263(1), 238-248.

El Kateb, A., Stalder, C., Neururer, C., Pisapia, C., \& Spezzaferri, S. (2016). Correlation between pollution and decline of Scleractinian Cladocora caespitosa (Linnaeus, 1758) in the Gulf of Gabes. Heliyon, 2(11), e00195.

El Zrelli, R., Courjeault-Radé, P., Rabaoui, L., Daghbouj, N., Mansour, L., Balti, R., Castet, S., Attia, F., Michel., S., \& Bejaoui, N. (2017). Biomonitoring of coastal pollution in the Gulf of Gabes (SE, Tunisia): Use of Posidonia oceanica seagrass as a bioindicator and its mat as an archive of coastal metallic contamination. Environmental Science and Pollution Research. https://doi.org/10.1007/s11356-017-9856-x.

El-Gamal, A. A., Peterson, R. N., \& Burnett, W. C. (2012). Detecting freshwater inputs via groundwater discharge to Marina Lagoon, Mediterranean Coast, Egypt. Estuaries and coasts, 35(6), 1486-1499.

Emrich, K., Martinez-Colon, M., \& Alegria, H. (2017). Is untreated seawage impacting coral reefs of Caye Caulker, Belize? Journal of Foraminiferal Research, 47(1), 20-33.

Erginal, A. E., Ekinci, Y. L., Demirci, A., Bozcu, M., Ozturk, M. Z., Avcioglu, M., et al. (2013). First record of beachrock on Black Sea coast of Turkey: Implications for Late Holocene sea-level fluctuations. Sedimentary Geology, 294, 294-302.

Espitalié, J., Deroo, G., \& Marquis, F. (1985). La pyrolyse Rock-Eval et ses applications. Première partie. Revue de l'Institut français du Pétrole, 40(5), 563-579.

Fernández-Torquemada, Y., \& Sánchez-Lizaso, J. L. (2005). Effects of salinity on leaf growth and survival of the Mediterranean seagrass Posidonia oceanica (L.) Delile. Journal of Experimental Marine Biology and Ecology, 320(1), 57-63.

Fernández-Torquemada, Y., Sánchez-Lizaso, J. L., \& GonzálezCorrea, J. M. (2005). Preliminary results of the monitoring of the brine discharge produced by the SWRO desalination plant of Alicante (SE Spain). Desalination, 182(1-3), 395-402.

Field, J. G., Clarke, K. R., \& Warwick, R. M. (1982). A practical strategy for analysing multispecies distribution patterns. Marine ecology progress series, 8(1), 37-52.

Frontalini, F., Buosi, C., Da Pelo, S., Coccioni, R., Cherchi, A., \& Bucci, C. (2009). Benthic foraminifera as bio-indicators of trace element pollution in the heavily contaminated Santa Gilla lagoon (Cagliari, Italy). Marine Pollution Bulletin, 58(6), 858-877.

Gacia, E., Invers, O., Manzanera, M., Ballesteros, E., \& Romero, J. (2007). Impact of the brine from a desalination plant on a shallow seagrass (Posidonia oceanica) meadow. Estuarine, Coastal and Shelf Science, 72(4), 579-590.

Gamito, S. (2008). Three main stressors acting on the Ria Formosa lagoonal system (Southern Portugal): Physical stress, organic matter pollution and the land-ocean gradient. Estuarine, Coastal and Shelf Science, 77(4), 710-720.

García-Pintado, J., Martínez-Mena, M., Barberá, G. G., Albaladejo, J., \& Castillo, V. M. (2007). Anthropogenic nutrient sources and loads from a Mediterranean catchment into a coastal lagoon: Mar Menor, Spain. Science of the Total Environment, 373(1), 220-239.
Gilabert, J. (2001). Seasonal plankton dynamics in a Mediterranean hypersaline coastal lagoon: The Mar Menor. Journal of Plankton Research, 23(2), 207-218.

Gooday, A. J. (2003). Benthic foraminifera (Protista) as tools in deepwater palaeoceanography: Environmental influences on faunal characteristics. Advances in Marine Biology, 46, 1-90.

Gupta, B. K. S., Turner, R. E., \& Rabalais, N. N. (1996). Seasonal oxygen depletion in continental-shelf waters of Louisiana: Historical record of benthic foraminifers. Geology, 24(3), 227-230.

Hallock, P., Lidz, B. H., Cockey-Burkhard, E. M., \& Donnelly, K. B. (2003). Foraminifera as bioindicators in coral reef assessment and monitoring: The FORAM Index. Environmental Monitoring and Assessment, 81(1-3), 221-238.

Hedges, J. I., Keil, R. G., \& Benner, R. (1997). What happens to terrestrial organic matter in the ocean? Organic Geochemistry, 27(5), 195-212.

Hintz, C. J., Chandler, G. T., Bernhard, J. M., McCorkle, D. C., Havach, S. M., Blanks, J. K., et al. (2004). A physicochemically constrained seawater culturing system for production of benthic foraminifera. Limnology and Oceanography: Methods, 2(6), $160-170$.

Hottinger, L., \& Halicz, E. R. (1993). Recent Foraminiferida from the Gulf of Aqaba, Red Sea (Vol. 33, p. 412) Ljubljana, Dela Opera.

Jorissen, F., Fontanier, C., \& Thomas, E. (2007). Paleoceanographical proxies based on deep-sea benthic foraminiferal assemblage characteristics. In C. Hillaire-Marcel \& A. de Vernal (Eds.), Proxies in late cenozoic paleoceanography (pp. 227-242). Amsterdam: Elsevier.

Kaiho, K. (1994). Benthic foraminiferal dissolved-oxygen index and dissolved-oxygen levels in the modern ocean. Geology, 22(8), 719-722.

Katz, B. J. (1983). Limitations of 'Rock-Eval'pyrolysis for typing organic matter. Organic Geochemistry, 4(3-4), 195-199.

Khiari, R., Mhenni, M. F., Belgacem, M. N., \& Mauret, E. (2010). Chemical composition and pulping of date palm rachis and Posidonia oceanica-A comparison with other wood and nonwood fibre sources. Bioresource Technology, 101(2), 775-780.

Kjerfve, B. (1986). Comparative oceanography of coastal lagoons. In D. A. Wolfe (Ed.), Estuarine variability (pp. 63-81). New York: Academic.

Kjerfve, B. (1994). Coastal lagoons. In B. Kjerfve (Ed.), Coastal lagoon processes (Vol. 60, pp. 1-8). Amsterdam: Elsevier Oceanographic Series.

Kjerfve, B., Schettini, C. A. F., Knoppers, B., Lessa, G., \& Ferreira, H. O. (1996). Hydrology and salt balance in a large, hypersaline coastal lagoon: Lagoa de Araruama, Brazil. Estuarine, Coastal and Shelf Science, 42(6), 701-725.

Lafargue, E., Marquis, F., \& Pillot, D. (1998). Rock-Eval 6 applications in hydrocarbon exploration, production, and soil contamination studies. Revue de l'institut français du pétrole, 53(4), 421-437.

Lamptey, E., \& Armah, A. K. (2008). Factors affecting macrobenthic fauna in a tropical hypersaline coastal lagoon in Ghana, West Africa. Estuaries and Coasts, 31(5), 1006-1019.

Langford, F. F., \& Blanc-Valleron, M. M. (1990). Interpreting RockEval pyrolysis data using graphs of pyrolizable hydrocarbons vs. total organic carbon (1). AAPG Bulletin, 74(6), 799-804.

Lepoint, G., Cox, A. S., Dauby, P., Poulicek, M., \& Gobert, S. (2006). Food sources of two detritivore amphipods associated with the seagrass Posidonia oceanica leaf litter. Marine Biology Research, 2(5), 355-365.

Lepoint, G., Dauby, P., Fontaine, M., Bouquegneau, J. M., \& Gobert, S. (2003). Carbon and nitrogen isotopic ratios of the seagrass Posidonia oceanica: Depth-related variations. Botanica Marina, 46(6), 555-561 
Livingstone, D. R., Lemaire, P., Matthews, A., Peters, L. D., Porte, C., Fitzpatrick, P. J., et al. (1995). Assessment of the impact of organic pollutants on goby (Zosterisessor ophiocephalus) and mussel (Mytilus galloprovincialis) from the Venice Lagoon, Italy: Biochemical studies. Marine Environmental Research, 39(1-4), 235-240.

Loeblich Jr, A. R. \& Tappan, H. (1994). Foraminifera of the Sahul Shelf and Timor Sea (p. 661.) Cushman Foundation for Foraminiferal Research, Special Publication 31.

Lopez, G. R., \& Levinton, J. S. (1987). Ecology of deposit-feeding animals in marine sediments. The Quarterly Review of Biology, 62(3), 235-260.

Louiz, I., Kinani, S., Gouze, M. E., Ben-Attia, M., Menif, D., Bouchonnet, S., et al. (2008). Monitoring of dioxin-like, estrogenic and anti-androgenic activities in sediments of the Bizerta lagoon (Tunisia) by means of in vitro cell-based bioassays: Contribution of low concentrations of polynuclear aromatic hydrocarbons (PAHs). Science of the Total Environment, 402(2), 318-329.

Mateu-Vicens, G., Box, A., Deudero, S., \& Rodríguez, B. (2010). Comparative analysis of epiphytic foraminifera in sediments colonized by seagrass Posidonia oceanica and invasive macroalgae Caulerpa spp. The Journal of Foraminiferal Research, 40(2), 134-147.

Martins, M. V. A., Helali, M. A., Zaaboub, N., Boukef-BenOmrane, I., Frontalini, F., Reis, D., et al. (2016). Organic matter quantity and quality, metals availability and foraminiferal assemblages as environmental proxy applied to the Bizerte Lagoon (Tunisia). Marine Pollution Bulletin, 105(1), 161-179.

Martins, M. V. A., Zaaboub, N., Aleya, L., Frontalini, F., Pereira, E., Miranda, P., et al. (2015). Environmental quality assessment of Bizerte Lagoon (Tunisia) using living foraminifera assemblages and a multiproxy approach. PLoS One, 10(9), e0137250.

Mateu-Vicens, G., Khokhlova, A., \& Sebastián-Pastor, T. (2014). Epiphytic foraminiferal indices as bioindicators in Mediterranean seagrass meadows. Journal of Foraminiferal Research, 44(3), 325-339.

Milker, Y., \& Schmiedl, G. (2012). A taxonomic guide to modern benthic shelf foraminifera of the western Mediterranean Sea. Palaeontologia electronica, 15(2), 1-134.

Mojtahid, M., Jorissen, F., Lansard, B., Fontanier, C., Bombled, B., \& Rabouille, C. (2009). Spatial distribution of live benthic foraminifera in the Rhône prodelta: Faunal response to a continental-marine organic matter gradient. Marine Micropaleontology, 70(3), 177-200.

Montague, C. L., \& Ley, J. A. (1993). A possible effect of salinity fluctuation on abundance of benthic vegetation and associated fauna in northeastern Florida Bay. Estuaries and Coasts, 16(4), 703-717.

Morel, F. M. M., \& Price, N. M. (2003). The biogeochemical cycles of trace metals in the oceans. Science, 300(5621), 944-947.

Murray, J. W. (2006). Ecology and applications of benthic foraminifera (p. 426). Cambridge: Cambridge University Press.

Mzoughi, N., Lespes, G., Bravo, M., Dachraoui, M., \& Potin-Gautier, M. (2005). Organotin speciation in Bizerte lagoon (Tunisia). Science of the Total Environment, 349(1), 211-222.

Nicolaidou, A., \& Nott, J. A. (1999). The role of the marine gastropod Cerithium vulgatum in the biogeochemical cycling of metals. Nato Science Series 2 Environmental Security, 59, 137-146.

Nixon, S. W. (1982). Nutrient dynamics, primary production and fisheries yields of lagoons. Oceanologica Acta, Special Issue, 357-371.

Nixon, S. W. (1995). Coastal marine eutrophication: A definition, social causes, and future concerns. Ophelia, 41(1), 199-219.

Nunez-Betelu, L., \& Baceta, J. I. (1994). Basics and application of Rock-Eval/TOC pyrolysis: An example from the uppermost
Paleocene/lowermost Eocene in the Basque Basin, Western Pyrenees. Munibe Ciencias naturales, 46, 43-62.

Ott, J. A. (1980). Growth and production in Posidonia oceanica (L.) Delile. Marine Ecology, 1(1), 47-64.

Otvos, E. G. (1985). Barrier platforms: Northern Gulf of Mexico. Marine Geology, 63(1-4), 285-305.

Phleger, F. B. (1965). Patterns of living marsh foraminifera in south Texas coastal lagoons. Boletin de la Sociedad Geologica Mexicana, 28(1), 1-44

Point, D., Monperrus, M., Tessier, E., Amouroux, D., Chauvaud, L., Thouzeau, G., et al. (2007). Biological control of trace metal and organometal benthic fluxes in a eutrophic lagoon (Thau Lagoon, Mediterranean Sea, France). Estuarine, Coastal and Shelf Science, 72(3), 457-471.

Polovodova, I., Nikulina, A., Schönfeld, J., \& Dullo, W. C. (2009). Recent benthic foraminifera in the Flensburg Fjord (western Baltic Sea). Journal of Micropalaeontology, 28(2), 131-142.

Romero, J., Pergent, G., Pergent-Martini, C., Mateo, M. A., \& Regnier, C. (1992). The detritic compartment in a Posidonia oceanica meadow: Litter features, decomposition rates, and mineral stocks. Marine Ecology, 13(1), 69-83.

Ruivo, M. (1973). Marine pollution and sea life (p. 664). London: Fishing News.

Sammari, C., Koutitonsky, V. G., \& Moussa, M. (2006). Sea level variability and tidal resonance in the Gulf of Gabes, Tunisia. Continental Shelf Research, 26(3), 338-350.

Sanchez-Lizaso, J. L., Romero, J., Ruiz, J., Gacia, E., Buceta, J. L., Invers, O., et al. (2008). Salinity tolerance of the Mediterranean seagrass Posidonia oceanica: Recommendations to minimize the impact of brine discharges from desalination plants. Desalination, 221(1-3), 602-607.

Schönfeld, J., Alve, E., Geslin, E., Jorissen, F., Korsun, S., \& Spezzaferri, S. (2012). The FOBIMO (FOraminiferal BIoMOnitoring) initiative-Towards a standardised protocol for soft-bottom benthic foraminiferal monitoring studies. Marine Micropaleontology, 94, 1-13.

Sfriso, A., Marcomini, A., \& Pavoni, B. (1987). Relationships between macroalgal biomass and nutrient concentrations in a hypertrophic area of the Venice Lagoon. Marine Environmental Research, 22(4), 297-312.

Sfriso, A., Pavoni, B., Marcomini, A., \& Orio, A. A. (1992). Macroalgae, nutrient cycles, and pollutants in the Lagoon of Venice. Estuaries and Coasts, 15(4), 517-528.

Shahidul, I. M., \& Tanaka, M. (2004). Impacts of pollution on coastal and marine ecosystems including coastal and marine fisheries and approach for management: A review and synthesis. Marine Pollution Bulletin, 48(7-8), 624-649.

Smith, V. H. (2003). Eutrophication of freshwater and coastal marine ecosystems a global problem. Environmental Science and Pollution Research, 10(2), 126-139.

Smith, B. N., \& Epstein, S. (1971). Two categories of ${ }^{13} \mathrm{C} /{ }^{12} \mathrm{C}$ ratios for higher plants. Plant Physiology, 47(3), 380-384.

Strasser, A., Davaud, E. \& Jedoui, Y. (1989). Carbonate cements in Holocene beachrock: example from Bahiret el Biban, southeastern Tunisia. Sedimentary Geology, 62, 23-46.

Taylor, D., Nixon, S., Granger, S., \& Buckley, B. (1995). Nutrient limitation and the eutrophication of coastal lagoons. Marine Ecology Progress Series, 127(1/3), 235-244.

Türkmen, M., Türkmen, A., \& Tepe, Y. (2011). Comparison of metals in tissues of fish from Paradeniz Lagoon in the coastal area of Northern East Mediterranean. Bulletin of Environmental Contamination and Toxicology, 87(4), 381.

Tyson, R. V. (1995). Abundance of organic matter in sediments: TOC, hydrodynamic equivalence, dilution and flux effects. In R. V. Tyson (Ed.), Sedimentary organic matter (pp. 81-118). Dordrecht: Springer. 
Van der Zwaan, G. J., Duijnstee, I. A. P., Den Dulk, M., Ernst, S. R., Jannink, N. T., \& Kouwenhoven, T. J. (1999). Benthic foraminifers: proxies or problems?: A review of paleocological concepts. Earth-Science Reviews, 46(1), 213-236.

Vela, A., Pasqualini, V., Leoni, V., Djelouli, A., Langar, H., Pergent, G., et al. (2008). Use of SPOT 5 and IKONOS imagery for mapping biocenoses in a Tunisian Coastal Lagoon (Mediterranean Sea). Estuarine, Coastal and Shelf Science, 79(4), 591-598.

Vizzini, S., Sarà, G., Mateo, M. A., \& Mazzola, A. (2003). $\delta^{13}$ C and $\delta^{15} \mathrm{~N}$ variability in Posidonia oceanica associated with seasonality and plant fraction. Aquatic Botany, 76(3), 195-202.

Vizzini, S., Sara, G., Michener, R. H., \& Mazzola, A. (2002). The role and contribution of the seagrass Posidonia oceanica (L.) Delile organic matter for secondary consumers as revealed by carbon and nitrogen stable isotope analysis. Acta Oecologica, 23(4), $277-285$.

Vousdoukas, M. I., Velegrakis, A. F., \& Plomaritis, T. A. (2007). Beachrock occurrence, characteristics, formation mechanisms and impacts. Earth-Science Reviews, 85(1-2), 23-46.

Walton, W. R., \& Sloan, B. J. (1990). The genus Ammonia Bruennich, 1772; Its geographic distribution and morphologic variability. Journal of Foraminiferal Research, 20(2), 128-156.

Whitlatch, R. B. (1981). Animal-sediment relationships in intertidal marine benthic habitats: Some determinants of deposit-feeding species diversity. Journal of Experimental Marine Biology and Ecology, 53(1), 31-45. 